\title{
The Royal Descent and the Past Glory of the Demak Sultanate as the Builders of Coastal Javanese Resistance in the Novel Penangsang (Tembang Rindu Dendam)
}

\author{
Sukarjo Waluyo*, Redyanto Noor, Ratna Asmarani \\ Faculty of Humanities, Diponegoro University, Indonesia;
}

\begin{abstract}
Arya Penangsang was a Duke of Jipang who ruled in the mid16th century. He is the grandson of Sultan Patah, the founder of the Sultanate of Demak. The Babad Tanah Djawi tells the story of Arya Penangsang killing Pangeran Mukmin to take back his father's rights. Pajang's attack succeeded in killing Arya Penangsang. The bad image of Arya Penangsang was built by the Sultanate of Pajang. Meanwhile, the Mataram Sultanate, Surakarta Palace, and Yogyakarta Palace continued for hegemony. Meanwhile, for the coastal community of Java, Arya Penangsang is a respected figure. The object of research is the novel Penangsang (Tembang Rindu Dendam) which was published in 2010. The purpose of this study is to explain the problem of resistance, namely disobedience in the context of the relationship between power and domination [1]. This study uses library and ethnographic methods by utilizing this new historicism $(\mathrm{NH})$ approach which links literary texts with non-literature. The results of this study indicate three important messages. First, people interpret their social environment in terms of their past history. Second, Arya Penangsang is a prince who became a local hero. Third, past history is a builder of cultural ties.
\end{abstract}

\section{Introduction}

Local identity in Indonesia has become a problem that has received much attention after the 1998 reform. For many cities and regions, this provides an opportunity to articulate their identity [2]. The articulation of the identity of Coastal Java can be seen in the novel Penangsang: Tembang Rindu Dendam by Nassirun Purwokartun [3]. Arya Penangsang, the main character in the novel, becomes essential. Most Javanese people believe that the Babad Tanah Djawi, which is the version of the rulers of inland Java, depicts Arya Penangsang as a temperamental, angry, rude, and power-hungry figure [4].

Meanwhile, he is a charismatic leader and local hero [5]. It is a cultural idea (with its symbols, myths, and ceremonies) to imagine an event not happening in the present. With these local figures, the community makes something that is imagined together [6]. Articulation, history, and identity are the concepts used in this article. Stuart Hall defines the articulation of cause as follows. "By the term, "articulation," I mean a connection or link which is not necessarily given in all cases, as *Corresponding Author: sukarjowaluyo@lecturer.undip.ac.id 
a law or a fact of life, but which requires particular conditions of existence to appear at all, which has to be positively sustained by specific processes, which is not "eternal" but constantly has to be renewed, which can under some circumstances disappear or be overthrown, leading to the old linkages being dissolved and new connections-re-articulation-being forged. It is also important that articulation between different practices does not mean that they become identical or that the one is dissolved into the other. Each retains its distinct determinations and conditions of existence. However, once an articulation is made, the two practices can function together, not as an "immediate identity" (in the language of Marx's "1857 Introduction") but as "distinctions within a unity" [7].

History or historical awareness is a form of mental image of the actions taken by someone. History through collective memory can form identities, such as ethnic identity, religion, racial awareness, and certain groups [8]. Identity is plural. The level of identity interest does not have to negate the interests of other identities [9]. This statement argues that social context is essential in building the identity of a group or society. Historical reasons and feelings of shared destiny become markers of the identity of a group or society.

The defeat in the succession of Demak leadership made Arya Penangsang imaged as an evil character. Sultan Hadiwijaya, as the victor, builds the story that Arya Penangsang was evil and rebellious. This was continued by the Sultanate of Mataram, the Surakarta Palace, and the Yogyakarta Palace for the sake of hegemony [10]. This article describes the construction and articulation of the identity of the Javanese Coastal community against the dominant discourse. The data is taken from the text of the novel Penangsang: Tembang Rindu Dendam (in this article written by $P T R D$ ) and the issues developing in the community.

This article results from research that uses the library and ethnographic methods by utilizing this new historicism approach (also called NH) which links literary texts with non-literary ones. Budianta, in the Journal Susastra, says that NH cannot be separated from post-structuralist theories such as Jaques Derrida's Deconstruction theory or the bond between sign and ideology expressed by Roland Barthes. NH relies on Michel Foucault's concept of power, which is a necessity that is always present in every human interaction, including language. NH also demonstrates a wealth of study across disciplines, history, literature, economics, and politics. Thus, the novel text of PTRD is not a stand-alone text [11].

\section{Articulation of the Identity of Coastal Java in the Novel PTRD}

The author starts with the problem of the succession of the Demak Sultanate. Thus, the novel PTRD has a way of telling about the main character. The author tries to avoid the opposite stigma between Coastal Java versus inland Java (Java Mataraman, centred in Surakarta and Yogyakarta). The story also opens with a description of the condition of the Demak Sultanate around the 16th century.

\subsection{History of the Greatness of the Sultanate of Demak as a Background}

The Sultanate of Demak is described as the largest Islamic kingdom in Java after the collapse of the Majapahit Kingdom. As the successor of Majapahit, Demak was an Islamic kingdom bringing a new era and enlightenment to the land of Java. Islam is the teaching of safety and peace which is the basis of the Sultanate of Demak. Demak was founded by Raden Patah (son of Brawijaya) and Islamic religious leaders (also known as Walisongo) to realize Islam in government. Peace in Java was maintained by inviting small kingdoms subordinate to Majapahit to join. Those who do not join are still respected, as long as they do not fight.

\section{Abad keenam belas Masehi.}

Tanah Jawa yang gulita tengah diterangi cahaya baru. 
Ngadiyati puniku.

"Itulah hati yang indah," demikian seorang pujangga menorehkannya dalam sebuah babad.

"Ketika itu, di Tanah Jawa telah masuk Islam semua, tiada lagi yang menentang. Para pertapa, begawan dan pembantunya, pengikut dan muridnya, banyak yang telah menerima keimanan. Dan, brahmana beserta para resinya telah berganti dengan ahliahli fikih ternama. Para pendeta berganti dengan ulama-ulama luhur, para zahid dan mu'ahid, mufti dan sulakha, para hukuma yang hebat.

Kesultanan Demak berdiri tegak. Dan, terus berkembang menyebarkan ajaran Islam ke seluruh tanah Jawa.

Selama 40 tahun Raden Patah berkuasa, telah mampu membawa Demak menjadi kerajaan terbesar di tanah Jawa. Sejajar dengan Kesultanan Malaka di Semenanjung Malaya dan Kesultanan Pasai di ujung utara Pulau Samudera (PTRD, 2010:3-4).

As a large kingdom, the Sultanate of Demak had a threat. The threat from within was that the territory of the former Majapahit Kingdom did not recognize the existence of Demak. The threat from outside was the presence of the Portuguese and Spanish, who began to dominate Malacca.

\subsection{Arya Penangsang's Defeat in the Succession of the Sultanate of Demak}

Under threat, the Sultanate of Demak experienced a succession that caused problems. Raden Patah, Sultan I Demak (1478-1518), died and was replaced by Pati Unus. Pati Unus came to power at the age of 18 and ruled for three years (1518-1521). He died at a young age and had no son. Pati Unus became Sultan Demak II because he was considered capable of advancing Jepara when he became the Duke of Jepara. He had also led an attack on the Portuguese in Malacca. He was also known as Pangeran Sabrang Lor (Prince who crossed the North Sea). The death of Pati Unus made the two brothers fight for the throne, Pangeran Sekar (brother) and Raden Trenggana (brother). Pangeran Sekar was finally killed by Raden Trenggana's son, Pangeran Prawata.

Raden Trenggana became Sultan Demak III and ruled for 25 years (1521-1546). In his leadership, the peace of the land of Java was getting stronger. Sultan Trenggana was killed in Panarukan while participating in the attack on the eastern part of Java. The death of Sultan Trenggana made the succession of the Sultanate of Demak between Pangeran Prawata and Arya Penangsang (son of Pangeran Sekar).

Namun, dengan wafatnya Trenggono, Kesultanan Demak Bintoro terguncang.

Keguncangan yang bermula dari dendam lama. Kematian Pati Unus yang belum mempunyai anak, meninggalkan pertikaian pada para penerusnya. Terjadi perebutan takhta antarsaudara, antara Pangeran Sekar dan Raden Trenggono. Dalam pertikaian antaranak Raden Patah itu, Pangeran Sekar terbunuh.

Dan, dengan wafatnya Trenggono, anak Pangeran Sekar yang bernama Haryo Penangsang berniat menuntut hak atas ayahnya (PTRD, 2010:5).

The novel PTRD reveals that another character (not a descendant of the Sultan Demak) was involved in the conflict. A very strong figure in the succession to the Demak throne after the death of Raden Trenggana and Pangeran Prawata. He was Jaka Tingkir, son-in-law of Raden Trenggana, whose name was Hadiwijaya when he was Duke of Pajang.

Bara kesumat mulai berkobar membakar Takhta Demak.

Karena dibalik kemelut tersebut, ada sosok yang juga menyimpan dendam lama.

Dan, tengah rindu untuk segera melampiaskan dengan merebut kekuasaan Kesultanan.

Peristiwa perebutan takhta kembali berulang dengan tegang.

Tembang rindu dendam pun lamat-lamat berkumandang.

Keni kinarya darsana, panglimbang ala lan becik, 


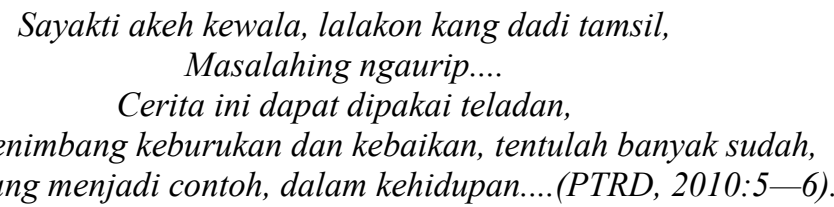

The novel PTRD also tells the struggle for the throne between Pangeran Sekar and Raden Trenggana in a flashback manner through Patih Mataun (a charismatic Jipang figure) and Sunan Kudus (a strong Islamic religious figure). They told the story of Pangeran Sekar's past in monologues and conversations with Arya Penangsang. Novel PTRD wants to illustrate that Arya Penangsang's attempt to reclaim the throne of Demak is his right. The feud resulted in the emergence of a new dynasty in Java. After successfully killing Arya Penangsang, Hadiwijaya moved the sultanate government from Demak to Pajang. Hadiwijaya, who became the Sultan of Pajang, was not a descendant of the Sultan Demak. Arya Penangsang's death is the climax of the political battle over who should inherit the throne of the Sultanate of Demak.

\subsection{Arya Penangsang is the Prince and Legal Heir of Sultanate of Demak}

Regarding why Arya Penangsang usurped his right to the Demak throne, the novel PTRD tells the context of Demak as the Sultanate of Islamic Java. In Javanese power, there is the term urut kacang, namely rights based on hierarchy (based on descendant order). Meanwhile, Islamic law recognizes the term qishosh, namely the right to avenge punishment by the heirs. These two things make the novel PTRD gives its blessing to Arya Penangsang's actions.

The term urut kacang gives the blessing that Pangeran Sekar (Arya Penangsang's father) has the right to the Demak throne to replace Pati Unus. He was Raden Trenggana's older brother. During a dispute, Raden Trenggana's son (Pangeran Prawata) killed Pangeran Sekar after a Friday prayer. This made Raden Trenggana able to become Sutan Demak III. Meanwhile, in the context of qishosh law, Arya Penangsang had two choices between forgiveness or revenge. Arya Penangsang is described as being in a neutral position. The revenge plan and the attempt to ask for the right to the throne of the Demak Sultanate were represented by Patih Mataun's attitude. This is seen in the following quote.

"Utang pati nyaur pati!"

Lelaki tua itu mendongakkan pandang. Ia memandangi tombak panjang yang menancap di dahan tanjung yang rindang.

"Utang nyawa harus dibayar dengan nyawa," desisnya mengulang.

Ia terkenang kata-katanya yang telah memantik kemarahan Penangsang (PTRD, 2010:7).

Ia terkenang kata-kata yang telah membuat Penangsang meradang.

Ia kembali terkenang. Ada darah yang mengalir di Kali Tuntang.

"Prewosto telah berhutang (PTRD, 2010:9).

'Prewosto' expresses Patih Mataun's hateful call to Pangeran Prawata, who once killed Pangeran Sekar. Patih Mataun hoped that Arya Penangsang would claim the right to the Demak throne. He was a witness to the killing of Pangeran Sekar on the banks of the Lusi River and Arya Penangsang's adoptive parents. Patih Mataun was a charismatic old figure who had served Jipang since he was young, when Pangeran Sekar (Arya Penangsang's father) became the Duke of Jipang. In the novel PTRD, Patih Mataun is told as the assistant of Arya Penangsang, Duke of Jipang, who was young and intelligent but struggled with principles.

\subsection{The Duchy of Jipang as the Builder of Historical Bonds}


The past power of the Jipang Duchy was a very wide area covering Cepu, Blora, Pati, Rembang, Lasem, and Bojonegoro. One of the daughters of the Duchy of Jipang was the wife of Raden Patah (Sultan Demak I) and the son of Pangeran Sekar, who later ruled in Jipang. The struggle for the throne of Demak with his younger brother, Raden Trenggana, killed him. Kushariyadi (52), Chairman of the Jipang Palace Foundation, revealed that Pangeran Sekar had a son named Arya Penangsang; when he was a teenager, he also continued to rule Jipang. After Pangeran Prawata (Sultan Demak IV) was killed, Arya Penangsang got involved in a political battle. His defeat in political intrigue and war against Hadiwijaya from Pajang made his life history written in 'black ink' by the Sultanate of Pajang. It lasted until the Sultanate of Mataram, the Surakarta Palace, and the Yogyakarta Palace [12].

In the context of the Javanese Coastal community, the history of Arya Penangsang as a descendant of the Sultan Demak and the Duke of Jipang is interpreted as the builder of historical bonds and collective memory, the builder of cultural ties and imagined communities. The cultural ties of the Javanese Coastal community are a subculture of Javanese culture. Cultural production in several forms, such as language, oral stories, clothing, and way of life, differs from the dominant Javanese culture. They are familiar with the expression "nek iya ya iya, nek ora ya ora" to express honesty. Also, the "congkrah agawe bubrah" expression interpret that talking about ancestors excessively makes people fight for rights and power.

\section{Conclusion}

The articulation and construction of the identity of the Javanese Coastal community in the novel PTRD provide a new perspective. This novel gives at least three important messages. First, people interpret them in terms of past history. Second, Arya Penangsang is a local hero. Third, past history is a builder of cultural ties and imagined community. Coastal Javanese culture is a subculture of Javanese culture. Cultural production in several forms, such as language, oral stories, clothing, and way of life, shows something unique. Finally, we realize that the meaning of articulation and identity by the Javanese Coastal community is related to cultural contestation.

\section{References}

1. Barker, C. Cultural Studies: Teori dan Praktik (Terjemahan oleh Nurhadi) 2004. Yogyakarta: Penerbit Kreasi Wacana. (2004)

2. Waluyo, Sukarjo. "The Existence of Jipang Village as a Collective Builder Cepu Community in Blora Regency”, E3S Web of Conferences 202/07012. (2020)

3. Purwokartun, Nassirun. Penangsang: Tembang Rindu Dendam. Jakarta: Tiga Kelana. (2010)

4. Olthoff, W.L. Babad Tanah Djawi (De prozaversie van Ngabèhi Kertapradja voor het eerst uitgegeven door J.J. Meinsma en getranscribeerd door W.L. Olthof. DordrechtHolland: Foris Publications. (1987)

5. Waluyo, Sukarjo. Arya Penanangsang: Potret Pertarungan Jawa Pesisir vs Jawa Pedalaman. Jogjakarta: Ombak. (2020)

6. Anderson, Benedict. Imagined Communities (Komunitas-komunitas Terbayang) (terj.). Yogyakarta: Insist dan Pustaka Pelajar. (2008)

7. Hall, Stuart.. Representation: Cultural Representation and Signifying Practice. London: SAGE Publication Ltd. (1997) 
8. Arnet, Ronald C. "Paulo Freire's Revolutionary Pedagogy: From a Story-Centered to a Narrative-Centered Communication Ethics". Journal of Qualitative Inquiry 2002. Vol 8. Hal 489. (2002)

9. Sen, Amartya. Kekerasan dan Ilusi tentang Identitas. Jakarta: Marjin Kiri. (2006)

10. Waluyo, Sukarjo. "Hegemoni Jawa Mataraman dalam Tari Soreng sebagai Ikon Budaya Kabupaten Magelang”, dalam Endogami 3/1:85-99. (2019)

11. Sen, Amartya. Kekerasan dan Ilusi tentang Identitas. Jakarta: Marjin Kiri. (2006)

12. The interview was conducted at the house of Kushariyadi (52) Demaan Village, Padangan (Bojonegoro) on January 7, 2018. 